\title{
Research and Practice on the Educational Model of "Society and Culture in English-speaking Countries"
}

\author{
Chengshou TONG
}

\author{
College of Foreign Languages Fujian Business University Fuzhou, Fujian350012, PRC \\ e-mail:tcs1219@126.com
}

\begin{abstract}
Foreign language majors have rich connotations, involving Chinese and Western cultures, thoughts and multiple ideologies. At the same time, since the release of the Guidance Outline for the Ideological and Political Construction of Higher Education Curriculum, a wave of "big ideological and political" pattern has been set off in China's colleges and universities. In this context, this paper takes the course "Society and Culture of English-speaking Countries" as an example to explore and practice the curriculum education model for foreign language majors. By reshaping the teaching content system, innovating teaching methods and methods, and optimizing the education evaluation system, the classroom can play the role of "main channel". Through the "three classes" in the course teaching, online and offline interaction, campus and campus mutual promotion, innovation and formation of the "curriculum ideological and political" education mode of "one major, two auxiliary and three combination". The results of the survey show that students have a high degree of satisfaction and recognition for the education mode of "Society and Culture of Englishspeaking Countries", and the "curriculum ideological and political" education mode has a significant effect.
\end{abstract}

\section{Keywords: curriculum; educational model; teaching practice}

\section{INTRODUCTION}

Under the background of the new era, the promotion of the "big ideological and political" education pattern has pointed out a clear direction for the development of ideological and political education in various universities in China. What kind of talents should be cultivated in universities, how to train them, and where should the cultivated talents be transported are all closely linked to ideological and political work. In 2020, the Ministry of Education of PRC formulated the "Guiding Outline for the Ideological and Political Construction of Higher Education Curriculum" (hereinafter referred to as the "Outline"), which clearly stipulates the strategic measures, target requirements, teaching system and content focus of colleges and universities to implement the ideological and political education work. Colleges and universities should uphold the principles of moral education in their teaching practice, and integrate moral education in the whole process and all-round way in the practice of ideological and political education in colleges and universities. Cultivating newcomers with firm ideals and convictions, Chinese feelings, and international perspectives is an educating proposition faced by foreign language education and teaching workers in the new era, and it is also an important force point for promoting the reform of "three-dimensional education" in colleges and universities. Focusing on the vertical field of college education, the foreign language major is a very cuttingedge subject, where the Eastern and Western ideological trends, cultures, and ideologies collide fiercely. This major and its subject setting not only enable students to master a foreign language knowledge and improve their communication skills, but also enable students to see the development trend of China and other countries in the world. With the issuance of the "Outline", the construction of the "big ideological and political" pattern has gradually become the main theme of the ideological and political education in colleges and universities. Teachers should give full play to the advantages of classroom teaching channels, perfectly integrate the content of ideological and political theory with foreign language teaching, and play a synergistic effect. Therefore, the development of the education model of "curriculum ideological and political" in foreign language majors can help schools improve the effectiveness of morality and cultivation, and enhance students' ideological and political awareness and personal accomplishment. 


\section{THE VALUE IMPLICATION OF EDUCATING STUDENTS IN THE COURSES OF FOREIGN LANGUAGE MAJORS}

In today's world, multicultural ideas blend and permeate each other, and Chinese and Western ideologies collide and rub against each other. With foreign language ability and good ideological and political training, it can help college students to better recognize, understand and connect with the world. Therefore, the implementation of the curriculum education model in foreign language majors can help college students to establish the correct "three views",i.e.views on life, values and the world, and treat foreign cultures with a scientific attitude.

\subsection{Curriculum education construction for foreign language majors is a powerful guarantee for keeping the ideological position}

In human ideology, language plays a carrier role. In essence, the process of students learning language is the process of accepting a certain ideology [1]. From the reform and opening up to the present, a large number of TV dramas, popular music and festivals have been introduced to China, and Western culture, products and ideologies have been permeated everywhere in daily life. In this context, the thinking mode of Chinese teenagers has also been greatly influenced by Western culture. Therefore, in the teaching practice of foreign language majors, teachers need to scientifically guide students' values, outlook on life and world outlook based on contemporary students' thinking dynamics and changes in external thinking trends. The innovative development of the course "Society and Culture in English-speaking Countries" can be combined with the new development of Marxism in the new era, and establish a strong cultural confidence for students.

\subsection{Curriculum education construction for foreign language majors is a solid foundation for telling Chinese stories well}

Foreign languages are important tools for communication and integration between China and foreign countries.They play an irreplaceable role in discourse transmission and conversion. In the process of inheritance and innovation of Chinese culture, college students can be said to be the backbone. Foreign language students have unique advantages in language and cultural exchanges. They can better spread Chinese culture and let Chinese stories pass on forever. The construction of "Curriculum Ideology" for foreign language majors will help foreign language majors understand their own history and culture, appreciate the world from the depth of Chinese civilization, and understand China from the breadth of international culture. Under the training of "curriculum ideological and political", students majoring in foreign languages in the new era can better convey Chinese culture and Chinese stories to the world, allowing the world to see a true and three-dimensional China, thereby expanding the volume of Chinese culture spreading abroad. The influence of shaping the soft power of Chinese culture.

\subsection{The construction of curriculum education for foreign language majors is a strong support for serving the national strategy}

In the context of the new era, the development of the "Belt and Road" continues to improve, and the "double cycle" strategy continues to deepen and become more practical, and the foreign language major will shoulder a more important mission. China's opening to the outside world is advancing in depth, and it is necessary to train a large number of new-age talents with excellent political quality, international cultural vision and Chinese cultural accumulation. In this context, the construction of curriculum education for foreign language majors will help enhance students' in-depth understanding and deep understanding of "Chinese system", "Chinese road", "Chinese theory", "Chinese plan" and "Chinese culture". From this starting point, foreign language ideological and political teaching can help a new generation of students stand on the international stage, use multiple languages and multiple expressions to explain China, express a firm national stand, and safeguard the interests of the motherland.

\subsection{The construction of curriculum education for foreign language majors is a powerful help in cultivating high-quality teachers}

In the process of curriculum education construction of foreign language majors, teachers play an important role, so they must improve their professional basic skills. Colleges and universities should provide professional teachers with a solid platform to understand Western culture. At the same time, they should also carry out socialist ideological value training to enhance the cultural confidence of the teacher group. In the practice of ideological and political education in colleges and universities, teachers should organically integrate the "genetic" of Chinese elements into the classroom teaching content. In the teaching practice of the "Society and Culture of English-speaking Countries" course, the realization of learning to promote teaching and teaching complement each other, through the construction of the "big ideological and political" pattern, to further improve the language teachers' self-cultivation and theoretical teaching level. 


\section{EXPLORATION AND PRACTICE OF THE EDUCATIONAL MODEL OF THE COURSE "SOCIETY AND CULTURE IN ENGLISH-SPEAKING COUNTRIES"}

"Society and Culture in English-speaking Countries" is one of the compulsory basic courses for many English majors in China. Take Fujian Business University as an example. Since the establishment of this course in 2002, it has implemented the course under the perspective of cross-cultural comparison between China and foreign countries for 16 years. It integrates online course resources, multimedia teaching resources, traditional teaching resources, and alumni enterprise resources by using the methods of co-teaching by Chinese and foreign teachers and integration of professional teachers and ideological and political teachers. In practice, it continues to carry out the teaching reform and exploration of curriculum education, and innovate to form the Curriculum Education Model of "One Main Channel, Two Supplements and Three Combinations" (see Figture 1 for details), to interpret the cultural differences between China and English-speaking countries, so that students can understand China and the overall trend of world development, thereby establishing strong cultural self- confidence and resolutely following the path of socialist development.

\section{1. "One main channel"-give full play to the "main channel" role of professional courses}

In order to realize the "main channel" function of professional courses, the university mainly focus on the following three aspects.

(1)Reshape the teaching content system and demonstrate the value leadership of moral education.

Colleges and universities should naturally integrate ideological and political elements into professional courses, integrate them with professional knowledge, and carry out ideological and political education for students in a subtle atmosphere [6]. In order for the ideological and political elements to be naturally reflected in the curriculum, relevant educational subjects must reshape the teaching system. College teachers can innovate the teaching content of the curriculum -"Society and Culture in English-speaking Countries"from the following aspects:

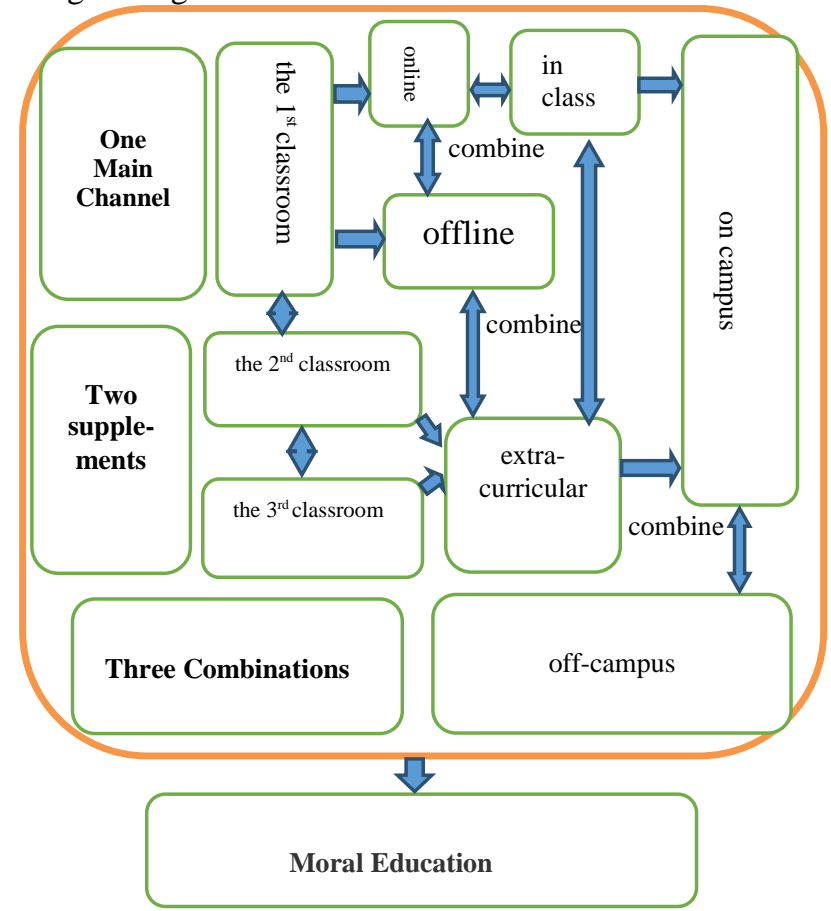

Figure 1 Curriculum Education Model of "One Main Channel, Two Supplements and Three

Combinations"

To begin with, reorganize the teaching content of "Society and Culture in English-speaking Countries"into eight modules. Focusing on global culture, world history, international politics, global economy, climate geography, etc., special topic teaching is carried out according to modules, and 1-2 teaching cases are designed for each topic, and teaching is based on cases.
Secondly, fully excavate ideological and politicalrelated elements in the teaching contents. "Society and Culture in English-speaking Countries"contains a large number of ideological and political elements, but these elements are not displayed intuitively, but are hidden behind knowledge points and scientific theories [6]. They need to be dissected and excavated before they can be 
discovered and used. The contents of "Society and Culture in English-speaking Countries"is allencompassing. It can present the characteristics of multicultural collision through the contents involving geography, history, politics, economy, culture, education, customs, festivals, etc. Therefore, teachers should fully explore the contrast and comparison between Chinese excellent traditional cultural elements and other multicultural elements in the course contents, highlighting the distinctive characteristics and profound heritage of Chinese civilization. The significance of China's "Four Great Inventions" to human civilization, the cultural and economic prosperity of the Tang, Song and Yuan dynasties, Zheng He's seven voyages to the West, and Xuanzang's eastward journey to Fusang, etc., deepen the sense of identity of foreign language students in colleges and universities for their own national culture and selfconfidence.

Thirdly, expand the contents of teaching and teaching materials. For example, the introduction of hot and key issues,such as he Sino-US trade war, the Meng Wanzhou incident, the comparison between China and foreign countries in the global fight against the epidemic, the incident of the American police kneeling and killing black people, the US interference in Hong Kong's national security legislation, the US riots, the verdict on the murder of Zhang Yingying, the American people's attack on the Capitol and attitudes of US politicians and the media towards it,etc.. Teachers can reshape teaching contents through hot topics, which can improve the effectiveness of curriculum education.

(2) Innovate teaching methods and means to highlight the dominant status of students

In Constructivist Theory, students occupy a central position. The theory emphasizes that students need to improve their learning initiative in order to further build their own unique knowledge framework. Therefore, the implementation of the curriculum ideological and political teaching mode requires a combination of initiative, enthusiasm, practicality, and emotion, so as to change the traditional preaching mode and allow students to actively participate in classroom teaching. This will increase the interaction between teachers and students, make the classroom atmosphere more active, and make the ideological and political courses more lively and interesting [3]. In order to arouse students' emotional resonance in learning, we adopted a "Student-Centered, Output-Oriented" Online and Offline Hybrid Teaching Model (see Figure 2 for details). The pre-class is mainly online, providing students with learning materials, background knowledge and textbook knowledge contents, such as texts, courseware, animations, short videos, etc. The purpose is to provide "scaffolding" for students' classroom case study. In class, teachers of colleges and universities adhere to the combination of online and offline teaching methods, make full use of online resources, create a variety of real case scenarios for students, and then guide students to think independently around cases or guide students to conduct collaborative learning, conversational communication and criticism around cases discuss, and finally achieve the teaching goals of professional learning and curriculum ideology. After class, it is also mainly online. Students are provided with expanded learning materials, like texts, animations, short videos, etc.,for extracurricular tasks such as writing reflection diaries to consolidate the contents learned in the classroom and to diffuse students' thinking and further develop their thinking ability as well.

In terms of teaching methods, we mainly adopt multiple teaching methods such as lectures, case explanations, presentations, speech contests, teacherstudent discussions, and debates between students,etc..After class, students are urged to collect information, participate in social practice, professional research, write papers, create diaries, hold forums, screenwriters and other activities. The combination of online and offline, in-class and extra-curricular, enhances students' enthusiasm for participation and experience, stimulates their internal motivation to learn, and helps them better understand and master the professional knowledge and ideological and political elements they have learned. The contents of learning is reflected in their own external actions. 


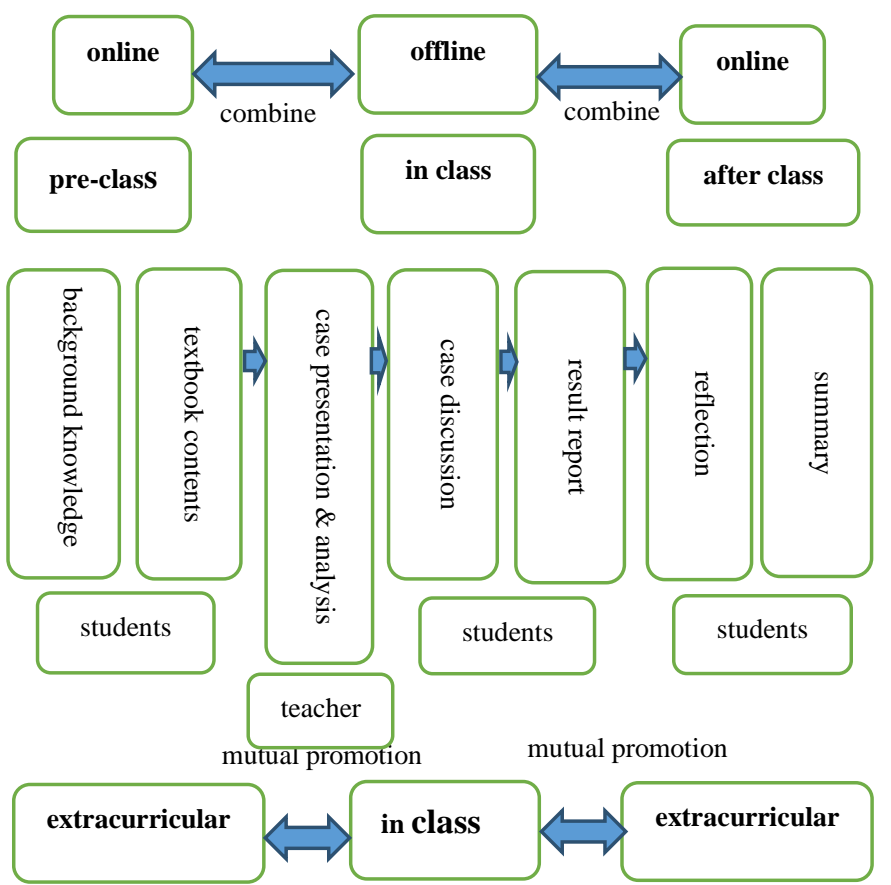

Figure 2 "Student-Centered, Output-Oriented"

Online and Offline Hybrid Teaching Model

Take Chapter One Geography, People and Language, an exclusive textbook for the course "Society and Culture of English-speaking Countries" (edited by Xie Fu, published by Foreign Language Teaching and Research Press), as an example. "Student-Centered, OutputOriented" Online and Offline Hybrid Teaching Model is adopted in the teaching design as follows.

\section{Before class:}

1.Online learning. Ask the students to watch the videos of Chapter One Geography,People and Language online and finish off the tasks accordingly.

2.Ask the students to collect vocabularies in English from French and think about the reasons.

\section{In class:}

1. Firstly, present the case on how popular Chinese is in Britain.

Based on "Daily Mail", 16 October 2013, British schoolchildren should learn to speak Chinese language Mandarin, Boris Johnson, the then London Mayor said that youngsters growing up in the UK needed to understand the culture and history of China to prepare them for the global battle for jobs. Mr. Johnson believes Mandarin should be taught in schools alongside traditional subjects like French and German, to reflect the power shift from West to East.

When asked whether all schoolchildren should learn Mandarin as standard, Mr. Johnson said: "Why not? Absolutely. My kids are learning it so why not? Definitely, definitely."
It marks a dramatic change in opinion for the senior Tory, who insisted in 2005 that "we do not need to teach our babies Mandarin" and claimed"China will not dominate the globe".

Earlier this year a study by the British Council and HSBC found three per cent of primary school teachers and nine per cent of secondary teachers said their school offered Mandarin lessons.(http://www.sohu.com/a/190341117_183132)

2. Secondly, ask students to analyze the case and then discuss the case based on the following questions in groups, then ask the representatives from each group to report their viewpoints.

1) Why did Boris Johnson, the present PM in UK, encourage all schoolchildren to learn Mandarin?

2) Why is there such a drastic change in Britain from "No Chinese" to "Yes Chinese"?

3) What do you think of the significance of English in today's world?

3. Thirdly, the teacher discusses the case and the questions with the students.

4. Fourthly, ask students to have a mini debate on the topic "Which language is more important, Chinese or English?"

5. Then, the teacher analyzes the student's debate and the case.

6. Finally, the teacher helps students to reach the conclusions. 


\section{After class:}

1.Write a reflection diary.

2.Think about why the Chinese language is becoming more and more popular around the world? What's the logic behind it?

The above-mentioned teaching design concept follows the concept of "student-oriented, outputoriented". Through independent thinking, case study, case analysis, case discussion, presentation on stage, classroom debate, writing reflection diary, etc., students' enthusiasm for classroom learning is fully stimulated, their personalized development is cultivated, students' understanding of professional knowledge and in-depth thinking about China's development trend are also effectively promoted.

A student wrote in the reflection diary: Through a semester learning combined with current political hot spots, case study, case analysis and discussion, I have a deep understanding of the greatness of the Socialist System with Chinese Characteristics. I want to study harder and contribute to the vigorous development of the motherland, so as to better shoulder the responsibilities and missions entrusted to our generation in the new era.

Some students also wrote in their reflection diaries: Through one semester learning of "Society and Culture of English-speaking countries", I have a more comprehensive understanding of Western countries. For example, a series of recent problems in Western countries, such as the inaction, dumping of the U.S. government during the epidemic,the White American Police Officer Derek Shavin Kneeled and Killed Black George Floyd, U.S. politicians' and media's attitudes towards the incident of people attacking the Capitol, .... which further clarify the true colors of "democracy, freedom, equality", "universal values" and "famous double standards" of Western countries headed by the United States.

(3)Reform the evaluation system of educating students to reflect diverse humanistic care

For a long time, when colleges and universities evaluate foreign language majors, the standards are too single, except for majors and courses, there are basically no other indicators. In order to establish a complete curriculum ideological and political evaluation system, we need to re-examine the original intention and essence of education, integrate students' values, emotions, and cognition into the evaluation process, and make the evaluation system full of humanistic and diversified characteristics [5]. Based on this, this course uses a combination of process evaluation evaluation and summative evaluation for teaching. Process evaluation includes classroom tests, case discussions, discussion results display, study skills, reflection logs, and further adopts multiple evaluation methods such as personal evaluation, student mutual evaluation, and teacher evaluation; summative evaluation (final exam) mainly incorporates ideological and political elements. In addition, we also use a combination of in-event, postevent and dynamic evaluation to refine the evaluation indicators to comprehensively improve students' learning and progress ability, analyze the effectiveness of students' knowledge learning and values shaping from multiple angles, and promote curriculum education.

\section{2. "Two supplements"-give full play to the education function of the second and third classrooms}

"Two supplements" mainly refers to the combination of the teaching methods, practical experience, and cultural communication characteristics of the first classroom and the second classroom to further optimize the educational practice system of the third classroom [2].

The first is to carry out a variety of foreign language activities in a normal way. For example, develop a daily campus English broadcast plan, organize an English film and television appreciation course once a week, a weekly foreign language corner, foreign teacher lectures, English salons, etc..In addition, some foreign language competition activities, such as speeches, dubbing, debates and other competitions, and a variety of foreign language quality development activities, such as bilingual evenings, carnivals, and British food festivals can also be held,so as to enable students to improve their foreign language communication skills, teamwork spirit, and innovative spirit, and to realize the power of Chinese culture and strengthen their cultural self-confidence. Secondly, in response to the current rapid development of the Internet, which is "everywhere and all time," colleges and universities need to occupy the "learning and educating positions" of the Internet in a timely manner, and gradually build a school-level media as the mainstay, and a college-level propaganda media as the supplement of the first and second classroom, and an all-round Internet education system based on class media.

\section{3. "Three Combinations"-Multiple coordination plays the "ensemble" of curriculum education}

It is pointed out in the "Outline" that when colleges and universities promote curriculum ideological and political work, they need to be integrated into all aspects of curriculum teaching and all aspects of talent training. There are three specific combinations: First, the combination of online and offline, that is, the combination of online guidance and offline guidance, to develop a mixed teaching model. In addition to classroom teaching, it is necessary to collect network resources online so that students can actively communicate with each other on the Internet, thereby 
enhancing the effectiveness of teaching. Second, the combination of inside and outside classes, that is, the combination of the first classroom with the second and third classrooms, breaks the barriers between the three classrooms. Third, the combination of inside and outside the school means mutual promotion between inside and outside the school. In the school, the first, second and third classrooms are used comprehensively, and at the same time, it pays attention to organize students to interact with foreign teachers and international students; outside the school, pay attention to organizing students for international large-scale conferences in Fujian, e.g."Sea Silk" Expo, Cross-Strait Economic and Trade Fair,China International Sporting Goods Expo,etc., which provide linguistic and voluntary services to enhance students' professional awareness and professionalism.

\section{An Empirical Study on the Educational Model of the Course "Society and Culture in English-speaking Countries"}

\subsection{Research questions}

(1) What kind of effect did the ideological and political education mode of the course "Society and Culture in English-speaking Countries" achieve?

(2) What is the attitude of the learners towards the ideological and political education mode of the "Society and Culture of English-speaking Countries" course?

\subsection{Research objects and research methods}

In the process of this research, this article mainly selects the second-year administrative class of a business English major of a university in Fujian Province as the research object. Assume that there are 2 groups in the control class and the experimental class, each with 64 people, and each with one teacher. All require the integration of ideological and political elements into classroom teaching. And the textbooks, teaching contents, progress, requirements, and class hours used in the four classes are the same. The only difference is the teaching method. The control group was taught using traditional offline methods, and the experimental group was taught using a combination of online and offline methods and case teaching methods. The teaching materials and cases are closely related to current political hot spots, such as Meng Wanzhou Incidents, Sino-US trade war, etc. The level of students was tested before and after the experiment, and after the experiment, a questionnaire survey was conducted on the students, and then a few students were randomly selected to conduct interviews. The duration of this experiment is one semester.

\subsection{Data collection and statistics}

Before the beginning and after the end of the experiment, the students were tested for professional level four ability respectively, the purpose is to understand the extent to which the curriculum education model affects the students' professional learning, and SPSS19.0 software was used to analyze the results of the two tests. In order to understand the true attitudes of students to the curriculum education model, we conducted a questionnaire survey on the research objects after the experiment is over. The contents of the questionnaire mainly includes students' attitudes towards the integration of ideological and political elements into the teaching of professional courses, the focus of students in the learning of professional courses, and the expectations of students in the learning of professional courses. In the process of this questionnaire survey, a total of 128 valid questionnaires were retrieved, and SPSS19.0 software was used to analyze the questionnaire data. After the questionnaire survey, we randomly selected 5 students from the experimental class and the control class to conduct interviews based on the content of the questionnaire. A total of 10 valid texts converted from recordings were obtained from the interview.

\subsection{Results and discussion}

(1) Comparison of results of pre-test and post-test

In order to understand the effectiveness of the curriculum education model, we selected two sets of professional level 4 simulation questions with basically the same difficulty. At the beginning and end of the semester, 128 students were tested before and after the test. The scores for the pretest and post-test were paired. The sample T test method is used for statistics, and the results are shown in Table 1.

Table 1 Comparison of the mean value of the pre-test and post-test results of the comparative class and the experimental class

\begin{tabular}{lllllr}
\hline Subject & Mean Value & Standard Error & T Value & Sig.(2-tailed) \\
\hline $\begin{array}{l}\text { Pre-test } \\
0.894\end{array}$ & Comparative Class & 56.943 & 1.057 & 0.133 \\
& & & & \\
& Experimental Class & 56.750 & 1.096 & \\
Post-test & Comparative Class 59.281 & 0.973 & -2.725 & 0.008 \\
& Experimental Class & 62.422 & 0.736 & \\
\hline
\end{tabular}

Observing the above table, we found that 128 students (64 in the control class and the experimental class respectively) were tested for TEM-4 before the start of the experiment. The Sig. value was 0.894 , which was greater than 0.05 , indicating that there was no significant difference in their performances and there is not much difference in the level of English. After the end of the experiment, TEM-4 was conducted again, and the Sig. value was 0.008 , which was less than 0.05 . This shows that there is a significant difference in students' 
performances, which determines that the student's English level has been significantly improved. However, compared with the control group, the experimental group's performance increased more significantly, indicating that the "Society and Culture of Englishspeaking Countries" course has a significant effect on improving the subjects' academic performance. Through interviews, it is found that most students agree with the education model proposed in "Society and Culture of English-speaking Countries". A student said: "After taking the course "Society and Culture in Englishspeaking Countries", we have changed our previous blind admiration of irrationality in European and American countries and have a deep understanding of' where China's self-confidence comes from'. [4]" Some students said: "I really like the combination of online and offline teaching methods in "Society and Culture of English-speaking Countries", especially the case teaching in offline classrooms. On the one hand, it is closely related to current affairs, such as the comparison of the anti-epidemic between China and the United States, the Sino-US trade war, the Meng Wanzhou incident, etc.; on the other hand, we have obtained preliminary answers to the difficult questions in our minds, such as the verdict on the murder of Zhang Yingying. Through the study of this course, we have a deeper understanding and

Table 2 Comparison of the attitudes of the students in the control group and the experimental group towards the curriculum education model

\begin{tabular}{|c|c|c|}
\hline Items & the Control Group & the Experimental Group \\
\hline $\begin{array}{l}\text { 1. I think the teacher has integrated } \\
\text { ideological and political elements in the } \\
\text { teaching of "Society and Culture of } \\
\text { English-speaking Countries". }\end{array}$ & $\begin{array}{l}\text { Yes } 90.63 \% \\
\text { No } 9.31 \%\end{array}$ & $\begin{array}{l}\text { Yes } 98.44 \% \\
\text { No } 1.56 \%\end{array}$ \\
\hline $\begin{array}{l}\text { 2. My attitude towards the integration of } \\
\text { ideological and political elements in the } \\
\text { teaching of "Society and Culture in } \\
\text { English-speaking Countries" is }\end{array}$ & $\begin{array}{l}\text { Very interested } 69.31 \% \\
\text { Interested } 15.06 \% \\
\text { Indifferent } 10.94 \% \\
\text { Not interested } 4.69 \% \\
\text { Completely not interested } 0\end{array}$ & $\begin{array}{l}\text { Very interested } 81.25 \% \\
\text { Interested } 14.06 \% \\
\text { Indifferent } 4.69 \% \\
\text { Not interested } 0 \\
\text { Completely not interested } 0\end{array}$ \\
\hline $\begin{array}{l}\text { 3. I think the teacher integrates } \\
\text { ideological and political elements into } \\
\text { the teaching of "Society and Culture in } \\
\text { English-speaking Countries". }\end{array}$ & $\begin{array}{l}\text { Very natural } 43.75 \% \\
\text { Natural } 40.63 \% \\
\text { Generally } 10.94 \% \\
\text { Not natural } 4.69 \% \\
\text { Very abrupt } 0\end{array}$ & $\begin{array}{l}\text { Very natural } 47.69 \% \\
\text { Natural } 47.62 \% \\
\text { Generally } 4.69 \% \\
\text { Not natural } 0 \\
\text { Very abrupt } 0\end{array}$ \\
\hline $\begin{array}{l}\text { 4. In the learning of "Society and Culture } \\
\text { in English-speaking Countries", I pay } \\
\text { more attention to }\end{array}$ & $\begin{array}{l}\text { Current political topics } 39.06 \% \\
\text { National culture } 62.5 \% \\
\text { Social life } 79.69 \% \\
\text { Professional related content } 100 \% \\
\text { Other contents } 60.94 \%\end{array}$ & $\begin{array}{l}\text { Current political topics } 82.81 \% \\
\text { National culture } 93.75 \% \\
\text { Social life } 45.31 \% \\
\text { Professional related content } 100 \% \\
\text { Other contents } 32.81 \%\end{array}$ \\
\hline $\begin{array}{l}\text { 5. The teacher made a comparison } \\
\text { between China and foreign countries in } \\
\text { the teaching of "Society and Culture in } \\
\text { English-speaking Countries". }\end{array}$ & $\begin{array}{l}\text { Yes } 100 \% \\
\text { No } 0\end{array}$ & $\begin{array}{l}\text { Yes } 100 \% \\
\text { No } 0\end{array}$ \\
\hline $\begin{array}{l}\text { 6. Teachers will express their opinions } \\
\text { and ideas in the course of "Society and } \\
\text { Culture in English-speaking Countries". }\end{array}$ & $\begin{array}{l}\text { Clear expression } 78.13 \% \\
\text { Fuzzy expression } 15.63 \% \\
\text { No expression } 6.25 \%\end{array}$ & $\begin{array}{l}\text { Clear expression } 100 \% \\
\text { Fuzzy expression } 0 \\
\text { No expression } 0\end{array}$ \\
\hline
\end{tabular}

understanding of the development trend of the world and China and Chinese characteristics. As young people in the new era, we need to work hard so that we can take on the responsibilities and beliefs given to ourselves by the times in the future. This also confirms the conclusion that "compared with the control group students, the experimental group has a more obvious increase in performance." Of course, is the improvement in academic performance due to the education model of the "Society and Culture of English-speaking Countries " course, or due to other courses and students' acquisition, or the combined effect of the aforementioned factors? It needs further study in the follow-up.

(2)Results of the questionnaire survey

At the end of the experiment, this article uses questionnaire surveys to conduct in-depth analysis of the experimental group and the control group, and compare the results of the survey to understand students' evaluation and attitudes towards the curriculum education model. The data analysis results are shown in Table 2. 


\begin{tabular}{|c|c|c|}
\hline $\begin{array}{l}\text { 7. In the course of "Society and Culture } \\
\text { in English-speaking Countries", in } \\
\text { addition to imparting professional } \\
\text { knowledge, teachers will also }\end{array}$ & $\begin{array}{l}\text { Broadcast relevant ideas about the } \\
\text { country, society and people } 85.94 \% \\
\text { Spread the core values of socialism } \\
75 \% \\
\text { Guidance on the cultivation of students' } \\
\text { personal qualities } 89.06 \% \\
\text { Guidance on career and life planning } \\
81.25 \%\end{array}$ & $\begin{array}{l}\text { Broadcast relevant ideas about the } \\
\text { country, society and people } 96.88 \% \\
\text { Spread the core values of socialism } \\
98.44 \% \\
\text { Guidance on the cultivation of students' } \\
\text { personal qualities } 87.5 \% \\
\text { Guidance on career and life planning } \\
84.38 \%\end{array}$ \\
\hline $\begin{array}{l}\text { 8. I think it is } \\
\text { greatest influence on the cultivation of } \\
\text { family and country feelings. }\end{array}$ & $\begin{array}{l}\text { The family imperceptible } \\
\text { influence } 15.63 \% \\
\text { Classroom teaching } 51.56 \% \\
\text { Social opinion orientation } 25 \% \\
\text { Others } 4.69 \%\end{array}$ & $\begin{array}{l}\text { The family imperceptible } \\
\text { influence } 10.94 \% \\
\text { Classroom teaching } 54.69 \% \text { Social } \\
\text { opinion orientation } 31.25 \% \text { Others } \\
3.13 \%\end{array}$ \\
\hline $\begin{array}{l}\text { 9. In addition to professional } \\
\text { knowledge, my biggest gain in the } \\
\text { course of "Society and Culture in } \\
\text { English-speaking Countries" is }\end{array}$ & $\begin{array}{l}\text { Learn to look at issues rationally and } \\
\text { critically, especially with regard to } \\
\text { Chinese and Western perspectives } \\
81.25 \% \\
\text { Learn to be human } 32.81 \% \\
\text { Enhance patriotism } 82.81 \% \\
\text { Firm ideals and beliefs } 82.81 \% \text { Enhance } \\
\text { the "four self-confidence" } 84.38 \% \\
\text { Others } 31.25 \%\end{array}$ & $\begin{array}{l}\text { Learn to look at issues rationally and } \\
\text { critically, especially with regard to } \\
\text { Chinese and Western perspectives } \\
96.99 \% \\
\text { Learn to be human } 34.38 \% \\
\text { Enhance patriotism } 100 \% \\
\text { Firm ideals and beliefs } 98.44 \% \\
\text { Enhance the "four } \\
\text { self-confidence" } 98.44 \% \\
\text { Others } 29.69 \%\end{array}$ \\
\hline $\begin{array}{l}\text { 10. I think the teacher's integration of } \\
\text { ideological and political elements into } \\
\text { the teaching of the "Society and Culture } \\
\text { of English-speaking Countries " course } \\
\text { has strengthened my ideals and beliefs, } \\
\text { thus clarifying the overall development } \\
\text { trend of China and the world. }\end{array}$ & $\begin{array}{l}\text { Very helpful } 37.5 \% \\
\text { Helpful } 42.19 \% \\
\text { Generally } 15.63 \% \\
\text { Nothing helpful } 4.69 \% \\
\text { No help at all } 0\end{array}$ & $\begin{array}{l}\text { Very helpful } 40.63 \% \\
\text { Helpful } 54.68 \% \\
\text { Generally } 4.69 \% \\
\text { Nothing helpful } 0 \\
\text { No help at all } 0\end{array}$ \\
\hline $\begin{array}{l}11 . \text { I hope that other courses will also } \\
\text { adopt similar teaching methods in the } \\
\text { "Society and Culture of English- } \\
\text { speaking Countries" course. }\end{array}$ & $\begin{array}{l}\text { Yes } 82.81 \% \\
\text { No } 17.19 \%\end{array}$ & $\begin{array}{l}\text { Yes } 100 \% \\
\text { No } 0\end{array}$ \\
\hline
\end{tabular}

It can be seen from Table 2 that the teaching satisfaction and recognition of the course "Society and Culture of English-speaking Countries" is maintained at a high level. $82.81 \%$ of the students in the control class and $100 \%$ of the experimental class hope that other courses will also adopt similar teaching methods in "Society and Culture of English-speaking Countries". Students have shown great interest in the implementation of the ideological and political course in the teaching of "Society and Culture in English-speaking Countries"; $84.37 \%$ of the experimental class and $95.31 \%$ of the experimental classes are interested in integrating thinking into the teaching of "Society and Culture in Englishspeaking Countries".In an interview, a student said: "During the Hong Kong riots, some young students participated in the riots, and even acted as leaders, which is heartbreaking. Hong Kong's education should be responsible for it. Therefore, ideological and political elements should be gradually integrated into the education process of professional courses in Hong Kong to strengthen students' patriotic beliefs." This student expressed the aspirations of many young students. This shows that contemporary young students have a good sense of responsibility, which confirms the effectiveness of the education model of "Society and Culture of English-speaking Countries" from another aspect .

The teaching model of "Society and Culture in English-speaking Countries" is very effective in educating people. Over half of the students believe that "classroom teaching has the greatest impact on the cultivation of home and country feelings". More than $80 \%$ of the students in the control class and $90 \%$ of the experimental class believe that "in addition to learning professional knowledge, they have learned to treat Chinese and Western issues rationally and critically, and strengthened their patriotism,they have strengthened their ideals and beliefs, strengthened the 'four selfconfidence',i.e.self-confidence in the path of socialism with Chinese characteristics, self-confidence in theory, self-confidence in system, self-confidence in culture, and have a more intuitive understanding of the development trend of the world and China." In addition, from students' responses to item 1 , item 5 , and item 7 , we can see foreign language professional teachers have strong curriculum ideological and political awareness. From the answers to item 3 and item 6 , it can be seen that foreign language professional teachers have strong curriculum ideological and political control abilities. In the process 
of the school's comprehensive implementation of curriculum ideological and political construction, teachers play a major role, so it is necessary to improve teachers' moral education awareness and abilities.

Satisfaction, recognition, and educational effectiveness of the experimental class are better than those of the control class, which shows that "StudentCentered, Output-Oriented" Online and Offline Hybrid Teaching Model has a very powerful advantage.

\section{CONCLUSION}

This article refers to the education model of "One Main Channel, Two Supplements and Three Combinations", focusing on combining the concepts of education and moral education, and integrating the imparting of knowledge and the cultivation of emotional values. In this way, while teaching students knowledge and skills, it can also penetrate and spread the value of ideas. The curriculum education model of "One Main Channel, Two Supplements and Three Combinations" makes the curriculum ideological and political construction work throughout classroom teaching, campus cultural life, cyberspace, practical learning and other links. On the one hand, it allows students to better understand the theoretical knowledge they have learned and apply them to life practice; on the other hand, it can also supervise teachers to take the lead. Passing ideological and political elements to students in a subtle atmosphere will ultimately play a role in fostering morality and improving the ability and effect of school talent training.

In the future construction and research of ideological and political models of foreign language professional courses, we need to pay attention to the professionalism of teaching language and the usability of tools. At the same time, we must pay attention to the consciousness attribute of the teaching language, and finally build a developable and inheritable foreign language professional curriculum education system. Through the continuous improvement of the education system, the moral education knowledge and adaptability of foreign language teachers will be further improved, curriculum construction and classroom teaching will be fully integrated, and the advantages of both will be used to improve the quality and effect of teaching.

\section{ACKNOWLEDGMENTS}

Chengshou TONG thanks team members of "Society and Culture of English-speaking Countries" course from College of Foreign Languages,Fujian Business University and anonymous reviewers.

This work was supported in part by Major Project of Undergraduate Education and Teaching Reform Research in Fujian Province in 2020 under Grant No.FBJG20200153, in part by Major Project of Research on Undergraduate Education and Teaching Reform of Fujian Business University in 2020 under Grant No.2020JGA02.

\section{REFERENCES}

[1] Yu Wujin. Theory of Ideology. Shanghai People's Publishing House, Shanghai, 2014.

[2] Gao Deyi, Zong Aidong. Curriculum ideological and political: the inevitable choice to effectively play the role of the main channel of classroom education. Journal of Ideological and Theoretical Education, vol.1, 2017, pp.31-34,.

[3] Wu Yan. Let the curriculum ideological and political construction blow a new wind in colleges and universities across the country. People's Daily Online-Education

Channel.

http://edu.gmw.cn/2020-

06/12/content_33906584.htm

[4] Xie Ting, Chen Xiaofeng. Stirring up the "ideological and political responsibility" and publishing the "ideological and political taste". Fujian Daily, vol.12, 2018, pp.1-6.

[5] $\mathrm{Xu}$ Tao. Constructing the education pattern of curriculum ideology and politics.GuangmingDaily.http://news.gmw.cn/2019 /10/18/content_33242834.htm

[6] China News Network. "Guiding Outline for Curriculum Ideological and Political Construction in Colleges and Universities" was published. http://edu.qianlong.com/2020/0609/4256565.shtml 